\title{
Effect of Organic and Bio-Fertilization on the Growth and Chemical Composition on Umbrella Papyrus (Cyperus alternifolius, L.) Plants
}

\author{
M. R. A. Hassan , A. H. M. El-Naggar and A.M. Fadl \\ Floriculture, Ornamental Horticulture and Landscape Gardening Dept., Faculty of Agric. \\ (El-Shatby), Alexandria Univ. Egypt.
}

\begin{abstract}
The present experiment was performed throughout two successive seasons of 2016 and 2017 at the Nursery of Floriculture, Ornamental Horticulture and Landscape Gardening, Faculty of Agriculture, Alexandria University, Egypt to investigate the effects of organic fertilizer and different levels of bio-fertilizers on the vegetative growth, flowering characteristics, rhizomes production and chemical composition of Cyperus alternifolius, L. plant. Split-plot was the experiment design in three replicates, and sixteen in each. The main plot represented the organic fertilizers (cattle manure) $(0,10,20$, and $30 \% \mathrm{~V} / \mathrm{V})$ were mixed with growing media. The sub-plot was bio fertilizer (sub-factor). The two biofertilizers used were Nitrobine and Phosphorein. $\left(\mathrm{B}_{0}=\right.$ control, $\mathrm{B}_{1}=5 \mathrm{~g}$ Nitrobine $/$ pot , $\mathrm{B}_{2}=5 \mathrm{~g}$ Phosphorein $/$ pot, $\mathrm{B}_{3}=5 \mathrm{~g}$ Nitrobine $+5 \mathrm{~g}$ Phosphorein / pot). The results indicated that adding organic fertilizer to growing media by $30 \% \mathrm{~V} / \mathrm{V}$ with fourth level of bio-fertilizers $\mathrm{B}_{3}(5 \mathrm{~g}$ Nitrobine $+5 \mathrm{~g}$ Phosphorein / pot $)$ Led to a significant increase of vegetative growth characteristics (plant height, stem length, leaf length , number of leaves / stem, number of stems/ plant and total vegetative fresh weight / plant) and number of days from planting to flowering, rhizomes production, as well as significant increase of chemical composition of leaves and rhizomes, (total chlorophylls contents (SPAD units) in the leaves and carbohydrates contents in rhizomes). It can be recommended that producing high quality umbrella papyrus plants for different decorative purposes in landscaping can be accomplished by addition $30 \%(\mathrm{~V} / \mathrm{V}$ ) cattle manure to growing media with the addition of bio-fertilizers at rate of $5 \mathrm{~g}$ Nitrobine $+5 \mathrm{~g}$ Phosphorein / pot as the best way to provide the needs the plant of fertilization.
\end{abstract}

Key words: Cyperus alternifolius, L, organic fertilizer, cattle manure, bio-fertilizers, Nitrobine, Phosphorein, semi aquatic plants.

\section{INTRODUCTION}

Cyperus alternifolius, L. belongs to the family Cyperaceae. It is native to north and tropical Africa. Cyperus alternifolius, L. considered from semi aquatic plants and with the common names of umbrella plant, umbrella papyrus, and umbrella sedge or umbrella palm. (Bailey, 1962).

Umbrella papyrus is now used primarily as graceful accent in water gardens and at the margins of pools or ponds. It has a valuable usage as wonderful unusual cut flower (Hasegawa et al., 1998-b) and in a wide variety of landscaping i.e., tropical looking accent plant, patio and pot plant (Hasegawa et al., 1998-a). Also it used in sewage treatment, as well as the reclamation of contaminated land with heavy metals. (Jones and Humphries 2002).

Energy saving, environment conservation, and pollution control have been the most pronounced issue nowadays all over the world. Minimizing chemical fertilization usage, organic gardens, and bio fertilization are now the new strategies in all agricultural domains around the world. (Samira and El-Tayeb,2008). Organic fertilizers are of paramount importance for their beneficial effects on the physical, chemical and biological properties of soil, cation exchange capacity and available mineral nutrients for plant productivity. However, the opportunities for organic agriculture to affect plant and its occupants in the new century will increase obviously. (Atowa, 2012). Recent investigations revealed that the application of organic fertilizers and/or bio-fertilizers to the soils can promote nutrients availability and plant uptake, increase crop yield, reduce inputs of chemical fertilizers and minimize environmental risks (Barsoom, 1998; Koreish et al., 2004).

It is known that organic fertilization and bio fertilization are of the most important factors affecting umbrella plants. However, no reports are available on production of umbrella papyrus under Egyptian conditions Several investigators studied the effects of organic fertilization and bio fertilization on ornamental plants i.e.,

In a pot experiment, EL-Naggar et al. (2004) on Cyperus papyrus, L. found that, addiding composted leaves to the different growing media were significant effect on the most of vegetative growth, flowering parameters, rhizomes productivity, total chlorophylls contents in leaves and total carbohydrates in rhizome. Sherif and ElNaggar (2005) found that, applying cattle manure and inoculation with bio-fertilizers significantly increased lamina length and width, leaves fresh and dry weights and number of flowers /rhizomes, flower fresh weight, roots dry weight and rhizomes fresh and dry weights compared to the mineral fertilizer (control). They added that cattle or poultry manures application in presence of bio-fertilizers 
significantly increased peduncle length of Calla lily (Zantedeschia aethiopical) plants. Hammam, et al. (2014) found that using the fertilization with compost ( 2 ton/fed.) + chicken manure ( 2 ton/fed.) $+100 \mathrm{~kg}$ feldspar $+100 \mathrm{~kg}$ rock phosphate mixed inoculation with Bacillus megatherium var. phosphaticum and B. circulanse were resulted the highest values of plant height, root length, number of tillers, fresh and dry weights of roots and shoots on Vetiver Plant (Vetiveria Zizanioides, L.). Satapathy, et al. (2016) Found that INM (Integrated Nutrient Management) practices involving inorganic fertilizer, Vermicompost and Bio fertilizer (Azospirillum and Phosphate solubilising bacteria) in different combinations had no significant influence on sprouting of gladiolus corms. However, it had significant influence on flowering and corm production in gladiolus.

The main objective of the research is to study the effect of organic fertilization and bio fertilization on the vegetative growth, flowering, rhizomes production and chemical composition of Cyperus alternifolius, L. plant.

\section{MATERIALS AND METHODS}

The pot experimental study was carried out at Nursery of Floriculture, Ornamental Horticulture, Faculty of Agriculture, Alexandria University, Egypt. throughout the two successive growing seasons of 2016 and 2017. The Cyperus alternifolius, L. rootstocks with an Averages weight of $75 \mathrm{~g}$ and had at least 8-10 buds were chosen for the present investigation. El-Fawakhry et al. (2004) The rootstocks (one rootstock / pot) were cultivated and horizontally laid in pots of $30 \mathrm{~cm}$ diameter packed the growing media containing sand + Loam ratio of $(1: 1 \mathrm{~V} / \mathrm{V})$, in a full sunny place on $25^{\text {th }}$ Feb, 2016 and $20^{\text {th }}$ Feb, 2017 in the first and second season, respectively until reaching the flowering stage.

The chemical analysis of the used medium indicated that it was containing 40.63, 487.5 and $102.11 \mathrm{mg} / \mathrm{kg}$ of $\mathrm{P}, \mathrm{K}$ and $\mathrm{N}$, respectively. The electrical conductivity (EC) was $0.81 \mathrm{~d} . \mathrm{S} \mathrm{m}^{-1}$ with a $\mathrm{pH}$ value of 7.85 .

Two Factors were involved in the present study. Four levels of organic fertilizers randomly arranged in the main plots, while the four bio-fertilizers levels occupied the sub-plots. Four levels of organic fertilizers (main-factor) $(0,10,20$, and $30 \% /$ pot $\mathrm{V} / \mathrm{V}$ were mixed with growing media). The chemical analysis of the used cattle manure in the present study was presented in Table 1 .

Bio-fertilizers (sub-factor) used were Nitrobine and Phosphorein $\left(\mathrm{B}_{0}=\right.$ control, $\mathrm{B}_{1}=5 \mathrm{~g}$ Nitrobine $/$ pot , $\mathrm{B}_{2}=5 \mathrm{~g}$ Phosphorein/pot, $\mathrm{B}_{3}=5 \mathrm{~g}$ Nitrobine +5 g Phosphorein / pot). The bio-fertilizers were divided into two equal doses. The first one was added immediately at planting and the second was added 30 days after planting. El-Naggar (2010).
Data were statistically analyzed as a split-plot design with three replications in 2016 and 2017 seasons. Comparisons of the studied treatments were carried-out by least significant difference at 0.05 according to Gomez and Gomez (1984).

Table 1. Chemical analysis of used cattle manure.

\begin{tabular}{|c|c|}
\hline Parameter & Results of Analysis \\
\hline $\mathrm{pH}$ & 7.73 \\
\hline E.C. $\mathrm{ds} / \mathrm{m}$ & 5.04 \\
\hline Organic C (\%) & 12.4 \\
\hline Organic matter $(\%)$ & 21.38 \\
\hline $\mathrm{K}(\%)$ & 0.20 \\
\hline $\mathrm{P}(\%)$ & 0.38 \\
\hline $\mathrm{C} / \mathrm{N}$ & 11.69 \\
\hline Total N (\%) & 1.06 \\
\hline
\end{tabular}
parameters, included; plant height $(\mathrm{cm})$, stem length $(\mathrm{cm})$, leaf length $(\mathrm{cm})$, number of leaves / stem, number of stems/ plant and total vegetative fresh weight / plant (g). While, flowering data number of days to flowering. In addition, rhizomes fresh weight $(\mathrm{g}) /$ pot were recorded. Chemical analysis of total chlorophyll contents (SPAD units) "Special Products Analysis Division." in leaves, and the total carbohydrates content in rhizomes were determined according to Herbert, et al. (1971).

\section{RESULTS AND DISCUSSION}

\section{I- Vegetative growth characteristics: Plant height (cm):}

Data illustrated in Table (2), showed that there was significantly difference between plant height by using different organic fertilizer treatments. There was a significant increment in plant height with increasing the levels of organic fertilizers in both seasons. The longest plant was obtained by using level of $30 \%$ organic fertilizer $(66.33$ and $66.01 \mathrm{~cm}$, respectively), while the shortest plant was obtained by using organic fertilizer level at $0 \%$ organic fertilizer (control) $(53.49$ and $48.36 \mathrm{~cm}$, respectively) in both seasons.

Furthermore, there was a significant increment in plant height by applications of bio-fertilizers compared to the control treatment in both seasons. However, the longest plant was obtained by using the fourth level of bio-fertilizers $\mathrm{B}_{3}$ ( $5 \mathrm{~g}$ Nitrobine $+5 \mathrm{~g}$ Phosphorein / pot) (63.51 and $60.32 \mathrm{~cm}$, respectively), while the shortest plant was produced by untreated plants $\mathrm{B}_{0}$ (control) (55.47 and $53.50 \mathrm{~cm}$, respectively) in the both seasons.

The interactions among the treatments of organic fertilizer and bio-fertilizers levels were significantly affected. In general the longest plant was produced by using 30\% organic fertilizer and the fourth level of bio-fertilizers $\mathrm{B}_{3}$ ( $5 \mathrm{~g}$ Nitrobine $+5 \mathrm{~g}$ Phosphorein / pot) (68.52 and $71.98 \mathrm{~cm}$, respectively), while the shortest plant was obtained by using $0 \%$ organic fertilizer (control) with $\mathrm{B}_{0}$ bio-fertilizers (control) 
(48.58 and $45.74 \mathrm{~cm}$, respectively ) in the both seasons.

Stem length (cm):

The data presented in Table (2) that stem length significantly increased by using different levels of organic fertilizer. The longest stem was obtained by using level $30 \%$ of organic fertilizer (57.35 and $62.09 \mathrm{~cm}$, respectively) while the shortest stem was obtained by using level $0 \%$ of organic fertilizer (control) ( 44.39 and $45.10 \mathrm{~cm}$, respectively ), in the both seasons.

On the other hand, the application of biofertilizers levels was gave a significant effect on stem length. The longest length produced by application $\mathrm{B}_{3}$ (5 g Nitrobine +5 g Phosphorein / pot) (53.22 and $56.08 \mathrm{~cm}$, respectively), while the lowest length was obtained by untreated plant $\mathrm{B}_{0}$ (control), in the both seasons.

The interactions between the using treatments of organic fertilizer and bio-fertilizers levels were significantly affected. The longest stem was produced by using $30 \%$ organic fertilizer and fourth level of bio-fertilizers $\mathrm{B}_{3}(5 \mathrm{~g}$ Nitrobine $+5 \mathrm{~g}$ Phosphorein / pot) (63.11 and $66.97 \mathrm{~cm}$, respectively), while the shortest length was obtained by using $0 \%$ organic fertilizer (control) with $\mathrm{B}_{0}$ biofertilizers (control) $(40.57$ and $44.26 \mathrm{~cm}$, respectively) in the both seasons.

Table 2: Averages of plant height $(\mathrm{cm})$, stem length $(\mathrm{cm})$ and Leaf length $(\mathrm{cm})$ of the Cyperus alternifolius, $L$ as affected by the organic, bio fertilizer and their interaction throughout of the two seasons 2016 and 2017.

\begin{tabular}{|c|c|c|c|c|c|c|c|c|c|c|}
\hline \multicolumn{11}{|c|}{ Plant height (cm) } \\
\hline \multicolumn{6}{|c|}{ First season } & \multicolumn{5}{|c|}{ Second season } \\
\hline \multirow{2}{*}{$\begin{array}{l}\text { Organic } \\
\text { fertilizer } \\
\text { (A) }\end{array}$} & \multicolumn{4}{|c|}{ Bio-fertilizers (B) } & \multirow{2}{*}{ Mean } & \multicolumn{4}{|c|}{ Bio-fertilizers (B) } & \multirow[b]{2}{*}{ Mean } \\
\hline & $\mathbf{B}_{0}$ & $\mathbf{B}_{1}$ & $\mathbf{B}_{2}$ & $\mathbf{B}_{3}$ & & $\mathbf{B}_{0}$ & $\mathbf{B}_{1}$ & $\mathbf{B}_{2}$ & $\mathbf{B}_{3}$ & \\
\hline $0 \%$ & 48.58 & 53.19 & 54.89 & 60.28 & 53.49 & 45.74 & 47.37 & 49.35 & 50.98 & 48.36 \\
\hline $10 \%$ & 53.21 & 54.38 & 54.38 & 57.96 & 55.40 & 50.67 & 53.25 & 54.10 & 56.43 & 53.61 \\
\hline $20 \%$ & 58.95 & 54.34 & 61.93 & 67.28 & 60.29 & 56.64 & 59.00 & 60.55 & 61.88 & 59.52 \\
\hline $30 \%$ & 61.15 & 67.50 & 68.16 & 68.52 & 66.33 & 60.96 & 63.90 & 67.20 & 71.98 & 66.01 \\
\hline Mean & 55.47 & 57.35 & 59.84 & 63.51 & & 53.50 & 55.88 & 57.80 & 60.32 & \\
\hline LSD0.05 & $\mathrm{A}=7.09$ & $\mathrm{~B}=2.65$ & $\mathrm{~A} * \mathrm{~B}$ & 5.30 & & $A=2.25$ & $\mathrm{~B}=1.02$ & $\mathrm{~A} * \mathrm{E}$ & $=2.04$ & \\
\hline \multicolumn{11}{|c|}{$\begin{array}{c}\text { Stem length }(\mathrm{cm}) \\
\end{array}$} \\
\hline \multicolumn{6}{|c|}{ First season } & \multicolumn{5}{|c|}{ Second season } \\
\hline \multirow{2}{*}{$\begin{array}{l}\text { Organic } \\
\text { fertilizer } \\
\text { (A) }\end{array}$} & \multicolumn{4}{|c|}{ Bio-fertilizers (B) } & & \multicolumn{4}{|c|}{ Bio-fertilizers (B) } & \\
\hline & $\mathbf{B}_{0}$ & $\mathbf{B}_{1}$ & $\mathbf{B}_{2}$ & $\mathbf{B}_{3}$ & Mean & $\mathbf{B}_{0}$ & $\mathbf{B}_{1}$ & $\mathbf{B}_{2}$ & $\mathbf{B}_{3}$ & Mean \\
\hline $0 \%$ & 40.57 & 45.33 & 46.31 & 45.36 & 44.39 & 44.26 & 43.83 & 45.47 & 46.87 & 45.10 \\
\hline $10 \%$ & 41.85 & 43.73 & 46.74 & 47.20 & 44.88 & 46.36 & 49.31 & 50.67 & 52.58 & 49.73 \\
\hline $20 \%$ & 47.01 & 46.90 & 50.99 & 57.22 & 50.53 & 52.50 & 55.18 & 56.75 & 57.88 & 55.58 \\
\hline $30 \%$ & 52.92 & 55.23 & 58.16 & 63.11 & 57.35 & 58.04 & 59.91 & 63.42 & 66.97 & 62.09 \\
\hline Mean & 45.59 & 47.80 & 50.55 & 53.22 & & 50.29 & 52.06 & 54.08 & 56.08 & \\
\hline LSD0.05 & $\mathrm{A}=3.95$ & $\mathrm{~B}=2.09$ & $\mathrm{~A} * \mathrm{~B}$ & 4.19 & & $\mathrm{~A}=1.58$ & $\mathrm{~B}=1.02$ & & $3=2.04$ & \\
\hline \multicolumn{11}{|c|}{ Leaf length $(\mathrm{cm})$} \\
\hline \multicolumn{6}{|c|}{ First season } & \multicolumn{5}{|c|}{ Second season } \\
\hline \multirow{2}{*}{$\begin{array}{l}\text { Organic } \\
\text { fertilizer } \\
\text { (A) }\end{array}$} & \multicolumn{4}{|c|}{ Bio-fertilizers (B) } & & \multicolumn{4}{|c|}{ Bio-fertilizers (B) } & \\
\hline & $\mathbf{B}_{0}$ & $\mathbf{B}_{1}$ & $\mathbf{B}_{2}$ & $\mathbf{B}_{3}$ & Mean & $\mathbf{B}_{\mathbf{0}}$ & $\mathbf{B}_{1}$ & $\mathbf{B}_{2}$ & $\mathbf{B}_{3}$ & Mean \\
\hline $0 \%$ & 16.63 & 16.95 & 17.77 & 18.28 & 17.40 & 15.70 & 16.80 & 17.76 & 18.56 & 17.20 \\
\hline $10 \%$ & 16.09 & 17.17 & 18.79 & 18.49 & 17.63 & 16.78 & 17.30 & 18.77 & 18.36 & 17.80 \\
\hline $20 \%$ & 17.35 & 17.81 & 18.34 & 18.78 & 18.07 & 17.75 & 18.24 & 22.10 & 23.66 & 20.44 \\
\hline $30 \%$ & 16.42 & 17.75 & 18.57 & 20.39 & 18.28 & 18.86 & 21.16 & 22.04 & 25.16 & 21.80 \\
\hline Mean & 16.62 & 17.42 & 18.36 & 18.98 & & 17.27 & 18.38 & 20.17 & 21.43 & \\
\hline LSD0.05 & $A=0.52$ & $\mathrm{~B}=0.52$ & $A * B$ & 1.05 & & $\mathrm{~A}=2.38$ & $\mathrm{~B}=0.78$ & $8 \quad A * \mathrm{E}$ & $=1.56$ & \\
\hline
\end{tabular}

L.S.D. $0.05=$ least significant differences at 0.05 of probability. 


\section{Leaf length (cm):}

Data given in Table (2), proved that the leaf length significantly increased by using different levels of organic fertilizers. The longest leaf length was obtained by using $30 \%$ and $20 \%$ organic fertilizer (18.28 and $18.07 \mathrm{~cm})$ in the first season. For the second season longest leaf length was obtained by using $30 \%$ organic fertilizer $(21.80 \mathrm{~cm})$. While the lowest length was obtained by using $0 \%$ organic fertilizer (control)(17.40 and $17.20 \mathrm{~cm}$, respectively), in the both season.

Moreover, the application of bio-fertilizers levels was observed a significant effect on leaf length. The longest length produced when an application $\mathrm{B}_{3}$ (18.98 and $21.43 \mathrm{~cm}$, respectively), while the lowest length was obtained by untreated plant $\mathrm{B}_{0}$ (control) (16.62 and $17.27 \mathrm{~cm}$, respectively), in two seasons.

Concerning to the interaction among the treatments of organic fertilizers and bio-fertilizers was significant effect on leaf length. The longest leaf was produced by using $30 \%$ organic fertilizer with fourth level of bio-fertilizers $B_{3}$ ( $5 \mathrm{~g}$ Nitrobine +5 g Phosphorein / pot) (20.39 and $25.16 \mathrm{~cm}$, respectively), while the shortest length was obtained by using $10 \%$ organic fertilizer and $0 \%$ organic fertilizer (control) with $\mathrm{B}_{0}$ bio-fertilizers (control) (16.09 and $15.70 \mathrm{~cm}$, respectively) in the both seasons.

\section{Number of leaves per stem:}

From the data in Table (3) it is clear that there was significant increment in number of leaves per stem of umbrella papyrus. The maximum numbers of leaves per stem were obtained by using levels $30 \%$ and $20 \%$ of organic fertilizer. The minimum number of leaves was obtained by using $0 \%$ (control) (16.24 and 17.23 leaf/stem, respectively) in the both seasons.

Moreover, there was significant effect of biofertilizers treatment on number of umbrella papyrus leaves in the two seasons. The best result was recorded when treated plants with $\mathrm{B}_{3}(5 \mathrm{~g}$ Nitrobine $+5 \mathrm{~g}$ Phosphorein / pot) (18.16 and 19.45 leaf/ stem, respectively).

Concerning to the interaction among the treatments of organic fertilizer and levels of biofertilizers in the both seasons. The most effective treatment was organic fertilizer at the level of $30 \%$ with $\mathrm{B}_{3}$ (5 g Nitrobine $+5 \mathrm{~g}$ Phosphorein / pot) (18.27 and 20.00 leaf/ stem). The Less effective treatment was organic fertilizer at the level of $0 \%$ (control) with $\mathrm{B}_{0}$ (control) (14.38 and 15.61 leaf/ stem).

\section{Number of stems per plant:}

Data given in table (3), prove that the main effect different levels of organic fertilizer was significant in the both seasons. The maximum numbers of stems were obtained by using level $30 \%$ of organic fertilizer (37.94 and 35.13 stems/plant, respectively). The minimum number of stems were obtained by using $0 \%$ (control) (30.08 and 29.41 stems/ plant, respectively) in the both seasons.

For bio-fertilizers levels, any of bio-fertilizers applications led to significant increases in the number of stems per plant. The largest number obtained when $\mathrm{B}_{3}(5$ g Nitrobine +5 g Phosphorein / pot) (37.16 and 34.91 stems/ plant, respectively) was used, while the lowest number was produced by untreated $\mathrm{B}_{0}$ (control) (33.19 and 29.30 stems/ plant, respectively), in the two seasons.

The interactions between using the levels of organic fertilizer and bio-fertilizers levels were not significant in the number of stems per plant in the first season, but there were significant difference in number of stems in the second season. The maximum numbers of stems were obtained by using $30 \%$ organic fertilizer with $\mathrm{B}_{3}(5 \mathrm{~g}$ Nitrobine $+5 \mathrm{~g}$ Phosphorein / pot) (39.44 stem/ plant), while the minimum number of stems were obtained by using $0 \%$ organic fertilizer (control) with $\mathrm{B}_{0}$ bio-fertilizers (control) (28.00 stems/ plant).

\section{Total vegetative fresh weight / plant (g):}

Data given in Table (3) proved that total fresh weight of vegetative growth were significant increased by using the organic fertilizer levels. The heaviest total fresh weight was obtained by using $30 \%$ organic fertilizer (149.12 and $146.05 \mathrm{~g} /$ plant, respectively), while the lowest total fresh weight was produced by using $0 \%$ organic fertilizer (control) (101.35 and $96.27 \mathrm{~g} /$ plant, respectively), in the both seasons.

Moreover, the application of bio-fertilizers levels was observed a significant effect on total fresh weight of vegetative growth. The heaviest in total fresh weight was produced by application $\mathrm{B}_{3}(5$ g Nitrobine +5 g Phosphorein / pot) (139.45 and $132.29 \mathrm{~g} /$ plant, respectively), while the lowest in total fresh weight was produced by untreated (control) (108.13 and $112.87 \mathrm{~g} /$ plant, respectively), in the both seasons.

Generally, the interactions between the using organic fertilizer and different levels bio-fertilizers, there were significant increased in fresh weight. The maximum in fresh weight was obtained by using $30 \%$ organic fertilizer with $\mathrm{B}_{3}(174.83$ and $165.41 \mathrm{~g} /$ plant, respectively), while the lowest in fresh weight was obtained by using $0 \%$ organic fertilizer (control) with $\mathrm{B}_{0}$ (control) (92.65 and $91.93 \mathrm{~g} /$ plant, respectively), in the both seasons.

In general, from the previous results show that using $30 \%$ of organic fertilizer with fourth level of biofertilizers $\mathrm{B}_{3}$ ( $5 \mathrm{~g}$ Nitrobine $+5 \mathrm{~g}$ Phosphorein / pot) led to significantly increased of vegetative growth characteristics (plant height, stem length, leaf length , number of leaves / stem, number of stems/ plant and total vegetative fresh weight / plant) compared to other treatments. 
Table 3: Averages of number of leaves / stem, number of stem / plant and total vegetative fresh weight per plant (g) of the Cyperus alternifolius, $\mathrm{L}$ as affected by the organic, bio fertilizer and their interaction throughout of the two seasons 2016 and 2017.

\begin{tabular}{|c|c|c|c|c|c|c|c|c|c|c|}
\hline \multicolumn{11}{|c|}{ Number of leaves / stem } \\
\hline \multicolumn{6}{|c|}{ First season } & \multicolumn{5}{|c|}{ Second season } \\
\hline \multirow{2}{*}{$\begin{array}{l}\text { Organic } \\
\text { fertilizer } \\
\text { (A) }\end{array}$} & \multicolumn{4}{|c|}{ Bio-fertilizers (B) } & \multirow{2}{*}{ Mean } & \multicolumn{4}{|c|}{ Bio-fertilizers (B) } & \multirow[b]{2}{*}{ Mean } \\
\hline & $\mathbf{B}_{\mathbf{0}}$ & $\mathbf{B}_{1}$ & $\mathbf{B}_{2}$ & $\mathbf{B}_{3}$ & & $\mathbf{B}_{\mathbf{0}}$ & $\mathrm{B}_{1}$ & $\mathbf{B}_{2}$ & $\mathbf{B}_{3}$ & \\
\hline $0 \%$ & 14.38 & 15.94 & 16.83 & 17.83 & 16.24 & 15.61 & 16.83 & 18.05 & 18.44 & 17.23 \\
\hline $10 \%$ & 15.55 & 17.16 & 18.72 & 18.16 & 17.39 & 17.00 & 18.77 & 19.05 & 19.50 & 18.58 \\
\hline $20 \%$ & 16.88 & 17.99 & 18.05 & 18.38 & 17.83 & 18.61 & 18.72 & 19.05 & 19.88 & 19.06 \\
\hline $30 \%$ & 17.66 & 17.44 & 18.02 & 18.27 & 17.84 & 18.72 & 19.16 & 19.66 & 20.00 & 19.38 \\
\hline Mean & 16.12 & 17.13 & 17.90 & 18.16 & & 17.48 & 18.37 & 18.95 & 19.45 & \\
\hline LSD0.05 & $\mathrm{A}=0.78$ & $30 \quad \mathrm{~B}=$ & 0.574 & $\mathrm{~A} * \mathrm{~B}=1.14$ & & $\mathrm{~A}=1.70$ & $\mathrm{~B}=\mathrm{C}$ & $37 \quad \mathrm{~A}^{* 1}$ & $3=0.75$ & \\
\hline \multicolumn{11}{|c|}{ Number of stem / plant } \\
\hline \multicolumn{6}{|c|}{ First season } & \multicolumn{5}{|c|}{ Second season } \\
\hline \multirow{2}{*}{$\begin{array}{l}\text { Organic } \\
\text { fertilizer } \\
\text { (A) }\end{array}$} & \multicolumn{4}{|c|}{ Bio-fertilizers (B) } & & \multicolumn{4}{|c|}{ Bio-fertilizers (B) } & \\
\hline & $\mathbf{B}_{0}$ & $\mathbf{B}_{1}$ & $\mathbf{B}_{2}$ & $\mathbf{B}_{3}$ & Mean & $\mathbf{B}_{\mathbf{0}}$ & $\mathbf{B}_{1}$ & $\mathbf{B}_{2}$ & $\mathbf{B}_{3}$ & Mean \\
\hline $0 \%$ & 28.99 & 29.33 & 29.33 & 32.66 & 30.08 & 28.00 & 28.33 & 30.66 & 30.66 & 29.41 \\
\hline $10 \%$ & 34.77 & 30.22 & 35.88 & 36.44 & 34.32 & 30.11 & 30.44 & 30.88 & 32.11 & 30.88 \\
\hline $20 \%$ & 34.33 & 37.33 & 39.10 & 39.33 & 37.52 & 28.22 & 30.88 & 30.88 & 37.44 & 31.86 \\
\hline $30 \%$ & 34.66 & 37.22 & 39.66 & 40.21 & 37.94 & 30.88 & 34.11 & 36.11 & 39.44 & 35.13 \\
\hline Mean & 33.19 & 33.52 & 35.996 & 37.16 & & 29.30 & 30.94 & 32.13 & 34.91 & \\
\hline LSD0.05 & $\mathrm{A}=4.33$ & $39 \quad \mathrm{~B}=$ & 3.171 & $A * B=N . S$ & & $\mathrm{~A}=3.71$ & $\mathrm{~B}=1$ & $33 \quad \mathrm{~A}^{* 1}$ & $3=2.66$ & \\
\hline \multicolumn{11}{|c|}{ Total vegetative fresh weight per plant $(g)$} \\
\hline \multicolumn{6}{|c|}{ First season } & \multicolumn{5}{|c|}{ Second season } \\
\hline \multirow{2}{*}{$\begin{array}{c}\text { Organic } \\
\text { fertilizer } \\
\text { (A) }\end{array}$} & \multicolumn{4}{|c|}{ Bio-fertilizers (B) } & & \multicolumn{4}{|c|}{ Bio-fertilizers (B) } & \\
\hline & $\mathbf{B}_{\mathbf{0}}$ & $\mathbf{B}_{1}$ & $\mathbf{B}_{2}$ & $\mathbf{B}_{\mathbf{3}}$ & Mean & $\mathbf{B}_{\mathbf{0}}$ & $\mathbf{B}_{1}$ & $\mathbf{B}_{2}$ & $\mathbf{B}_{3}$ & Mean \\
\hline $0 \%$ & 92.65 & 100.63 & 101.12 & 110.98 & 101.35 & 91.93 & 93.75 & 97.93 & 101.46 & 96.27 \\
\hline $10 \%$ & 97.69 & 107.34 & 112.15 & 127.55 & 111.18 & 103.22 & 106.67 & 112.87 & 123.86 & 111.66 \\
\hline $20 \%$ & 119.41 & 132.99 & 138.45 & 144.43 & 133.82 & 121.75 & 127.58 & 133.73 & 138.43 & 130.37 \\
\hline $30 \%$ & 122.75 & 143.40 & 155.48 & 174.83 & 149.12 & 134.58 & 133.06 & 151.14 & 165.41 & 146.05 \\
\hline Mean & 108.13 & 121.09 & 126.80 & 139.45 & & 112.87 & 115.27 & 123.92 & 132.29 & \\
\hline LSD0.05 & $\mathrm{A}=15.43$ & $3 \mathrm{~B}=$ & $5.75 \mathrm{~A}^{*} \mathrm{I}$ & $\mathrm{B}=11.51$ & & $\mathrm{~A}=9.43$ & $\mathrm{~B}=3$ & & $* \mathrm{~B}=7.51$ & \\
\hline
\end{tabular}

L.S.D. $0.05=$ least significant differences at 0.05 of probability.

N.S $=$ Non- significant differences at 0.05 of probability.

The increment of the previous characteristics of vegetative growth due the role organic fertilization and bio fertilization could be explained by enhancing the cell division rate and cell enlargement. (Shalaby and El-Nady, 2008). Additionally, organic fertilization and bio fertilization is a very important for supplying the plants with their nutritional requirement without having an undesirable impact on the environment (Sherif and El-Naggar 2005). Furthermore, this increasing in vegetative growth might be attributed to the effect of organic fertilizer that improves physical, chemical, and biological properties of soil; that is, increasing soil organic matter, cation exchange capacity, water holding capacity and availability of mineral nutrients, this in turn, increases vegetative growth (Al-Fraihat et al.,
2011). These results may be attributed due to the physiological roles of vitamins and amino acids produced by microorganism which led increased the metabolic processes role and levels of endogenous hormones in treated plants, (Chaliakhyan, 1957). As finding could be related to the important role of microorganism such as nitrogen fixing bacteria, (NFB) Azotobacter or phosphate solubilizing bacteria (PSB) on improving the microbiological activity in the rhizosphere (Ridvan, 2009).

The previous results of vegetative growth were in harmony with those obtained by EL-Naggar et al. (2004) on Cyperus papyrus. L, Sherif and ElNaggar (2005) on Calla lily plants., Godse et al. (2006) on gladiolus, Kiran, et al. (2007) on Dahlia pinnata., Kengne, et al, (2008) on Cyperus papyrus. L., Abdou, et al, (2013) on Gladiolus grandiflorus 
cv. Eurovision plant., Chaudhary et al. (2013) on gladiolus, Hammam, et al. (2014) on (Vetiveria zizanioides, L. Nash), El- Deeb (2016) on gladiolus Gladiolus grandiflorus L. cv. "White Prosperity"., and Yathindra, et al. (2016) on Strelitzia reginae L.

\section{II- Flowering characteristics: \\ Number of days to flowering:}

Data in Table (4), showed that, the main effect of organic fertilizer was highly significant on the number of days to flowering. The shortest period between planting and flowering (137.88 and 131.33 days, respectively) was recorded with $0 \%$ organic fertilizer (control). The treatment of $30 \%$ organic fertilizer led to delay of flowering (172.10 and 159.66 days, in the both seasons, respectively). Fourth level of bio-fertilizers $\mathrm{B}_{3}(5 \mathrm{~g}$ Nitrobine $+5 \mathrm{~g}$ Phosphorein / pot) led to increasing the time required from planting to flowering (165.10 and 154.69 days, respectively). While the shortest period from planting to flowering (153.08 and 142.52 days, respectively) was recorded by control treatment, in both seasons.

The interactions between organic fertilizer and bio-fertilizers were significant leading to an increase in number of days to flowering. Generally, the longest period between planting and flowering (176.32 and 171.11 days, respectively) were recorded with $30 \%$ organic fertilizer with fourth level of bio-fertilizers $\left(\mathrm{B}_{3}\right)$. While the shortest period were recorded with control (124.88 and 126.88 days, respectively), in the both seasons.

Increasing in period of transplanting to flowering might be attributed to the important role of microorganism such as nitrogen fixing bacteria, (NFB) Azotobacter or phosphate solubilizing bacteria (PSB) Bacillus megaterium and potassium solubilizing bacteria (KSB) B. circulans, on improving the microbiological activity in the rhizosphere or contributed and solubilize essential minerals, making scarce nutrients more available to the plant. Moreover, production of growth promoting substances or organic acids, that could lead to a stimulate several physiological changes giving a better growth plant more tolerance to stresses (El-Haddad et al., 1993). Moreover, organic materials can reduce the P-sorption capacity of the soil, enhance $\mathrm{P}$ availability, improve $\mathrm{P}$ recovery or result in better utilization by plants. Organic materials add Carbon into the soil provides substrate for microbial growth, and subsequent microbial activity. The turnover resulting from the decomposition of organic materials improves the nutrient cycling and availability to the plants especially, $\mathrm{N}$ and $\mathrm{P}$, which improved root development and subsequently vegetative growth (Iyamuremye and Dick, 1997). These results are in agreement with that reported by EL-Naggar et al. (2004) on Cyperus papyrus, L. and Kengne, et al,
(2008) on Echinochloa pyramidalis and Cyperus papyrus.

\section{III- Rhizomes and roots characteristics: \\ Rhizomes fresh weight per pot (g):}

Data illustrated in Table (4), showed that there were significant difference between the rhizomes fresh weight by using different organic fertilizer levels. The heavy rhizomes fresh weight was obtained by using 30\% organic fertilizer (165.29 and $169.14 \mathrm{~g} /$ pot, respectively). The lowest rhizomes fresh weight produced by untreated (control)(135.77 and $134.70 \mathrm{~g} /$ pot, respectively), in the both seasons.

For bio-fertilizers levels, any of bio-fertilizers applications led to significant increases in rhizomes fresh weight as compared with the control treatment $\left(\mathrm{N}_{0}\right)$. In generally, the maximum fresh weight was obtained when using $\mathrm{B}_{3}$ (166.54 and $169.43 \mathrm{~g} / \mathrm{pot}$, respectively), while the lowest fresh weight was obtained by using untreated $\mathrm{B}_{0}$ (control) (136.97 and $135.77 \mathrm{~g} /$ pot, respectively), in the both seasons.

General, the interactions between the using levels organic fertilizer and bio-fertilizers levels, there were significant differences in rhizomes fresh weight. The maximum fresh weight was obtained by using level $30 \%$ organic fertilizer with $\mathrm{B}_{3}$ (189.27 and $193.13 \mathrm{~g} / \mathrm{pot}$, respectively), while the lowest fresh weight was obtained by using $0 \%$ organic fertilizer with $\mathrm{B}_{0}$ untreated (control)(121.00 and $117.14 \mathrm{~g} /$ pot, respectively), in the both seasons.

These results can be attributed to the role of organic fertilizers and bio-fertilizers in the provision of nutrients. In addition, these results may be due to the physiological roles of vitamins and amino acids produced by microorganism which led increased the metabolic processes role and levels of endogenous hormones, i.e., IAA and $\mathrm{GA}_{3}$ (Chaliakhyan, 1957).

These results were in harmony with those obtained by Jena, et al. (1999) on Curcuma longa cv., Koura, (2001) on Canna indica, L., EL-Naggar et al. (2004) on Cyperus papyrus, L. , Sherif and El-Naggar (2005) on Calla lily (Zantedeschia aethiopical) plants. ,Kengne, et al. (2008) on Echinochloa pyramidalis and Cyperus papyrus. L., and Torkashvand, et al. (2015) on Strelitzia reginae.

\section{IV-Chemical analysis:}

Total chlorophylls contents (SPAD units) in the leaves:

Data given in Table (5), proved that the leaf total chlorophyll contents significant increased by using different organic fertilizer levels. The increases in the leaf total chlorophyll contents was obtained by using level $30 \%$ organic fertilizer (40.76 and 41.74 SPAD, respectively), while the lowest leaf total chlorophyll contents was obtained by untreated plants (control) (30.57 and 33.90 SPAD, respectively) in the both seasons 2016 and 2017. 
Table 4: Averages of number of days to flowering and rhizomes fresh weight (g) of the Cyperus alternifolius, $\mathrm{L}$ as affected by the organic, bio fertilizer and their interaction throughout of the two seasons 2016 and 2017.

\begin{tabular}{|c|c|c|c|c|c|c|c|c|c|c|}
\hline \multicolumn{11}{|c|}{ Number of days to flowering } \\
\hline \multicolumn{6}{|c|}{ First season } & \multicolumn{5}{|c|}{ Second season } \\
\hline \multirow{2}{*}{$\begin{array}{l}\text { Organic } \\
\text { fertilizer } \\
\text { (A) }\end{array}$} & \multicolumn{4}{|c|}{ Bio-fertilizers (B) } & \multirow[b]{2}{*}{ Mean } & \multicolumn{4}{|c|}{ Bio-fertilizers (B) } & \multirow[b]{2}{*}{ Mean } \\
\hline & $\mathbf{B}_{\mathbf{0}}$ & $\mathbf{B}_{1}$ & $\mathbf{B}_{2}$ & $\mathbf{B}_{3}$ & & $\mathbf{B}_{0}$ & $\mathbf{B}_{1}$ & $\mathbf{B}_{2}$ & $\mathbf{B}_{3}$ & \\
\hline $0 \%$ & 124.88 & 137.88 & 143.88 & 144.88 & 137.88 & 126.88 & 129.11 & 130.22 & 139.11 & 131.33 \\
\hline $10 \%$ & 154.22 & 163.33 & 167.33 & 168.77 & 163.41 & 131.88 & 136.66 & 144.22 & 145.11 & 139.47 \\
\hline $20 \%$ & 166.21 & 168.55 & 169.33 & 170.44 & 168.63 & 160.77 & 149.00 & 159.22 & 163.44 & 158.11 \\
\hline $30 \%$ & 166.99 & 170.88 & 174.21 & 176.32 & 172.10 & 150.55 & 156.11 & 160.88 & 171.11 & 159.66 \\
\hline Mean & 153.08 & 160.16 & 163.69 & 165.10 & & 142.52 & 142.72 & 148.63 & 154.69 & \\
\hline LSD0.05 & $A=8$ & $44 \quad \mathrm{~B}=$ & 5.27 & $\mathrm{~A} * \mathrm{~B}=1$ & .55 & $A=11$ & & $3=6.75$ & $\mathrm{~A} * \mathrm{~B}=$ & 13.51 \\
\hline
\end{tabular}

Rhizomes fresh weight (g)

\begin{tabular}{|c|c|c|c|c|c|c|c|c|c|c|}
\hline \multirow{3}{*}{$\begin{array}{l}\text { Organic } \\
\text { fertilizer } \\
\text { (A) }\end{array}$} & \multicolumn{4}{|c|}{ First season } & \multirow{3}{*}{ Mean } & \multicolumn{5}{|c|}{ Second season } \\
\hline & \multicolumn{4}{|c|}{ Bio-fertilizers (B) } & & \multicolumn{4}{|c|}{ Bio-fertilizers (B) } & \multirow[b]{2}{*}{ Mean } \\
\hline & $\mathbf{B}_{0}$ & $\mathbf{B}_{1}$ & $\mathbf{B}_{2}$ & $\mathbf{B}_{3}$ & & $\mathbf{B}_{0}$ & $\mathbf{B}_{1}$ & $\mathbf{B}_{2}$ & $\mathbf{B}_{3}$ & \\
\hline $0 \%$ & 121.00 & 140.44 & 137.12 & 144.53 & 135.77 & 117.14 & 136.50 & 139.64 & 145.50 & 134.70 \\
\hline $10 \%$ & 145.27 & 145.88 & 150.06 & 155.52 & 149.18 & 140.50 & 148.25 & 156.94 & 167.52 & 153.30 \\
\hline $20 \%$ & 146.54 & 152.38 & 171.06 & 176.83 & 161.70 & 146.09 & 154.60 & 170.05 & 171.58 & 160.58 \\
\hline $30 \%$ & 135.08 & 163.21 & 173.61 & 189.27 & 165.29 & 139.36 & 165.95 & 178.14 & 193.13 & 169.14 \\
\hline Mean & 136.97 & 150.48 & 157.96 & 166.54 & & 135.77 & 151.32 & 161.19 & 169.43 & \\
\hline LSD0.05 & $\mathrm{A}=11 . \mathrm{C}$ & $\mathrm{B}=$ & $8.393 t$ & $* \mathrm{~B}=16$. & & $\mathrm{A}=6.34$ & $\mathrm{~B}=6$ & $1 \mathrm{~A} * \mathrm{~B}$ & 12.01 & \\
\hline
\end{tabular}

L.S.D. $0.05=$ least significant differences at 0.05 of probability.

Table 5: Averages of Total chlorophylls contents (SPAD units) in the leaves and total carbohydrates contents in rhizomes $(\mathrm{mg} / \mathrm{g}$ D.W.) of the Cyperus alternifolius, $\mathrm{L}$ as affected by the organic, bio fertilizer and their interaction throughout of the two seasons 2016 and 2017.

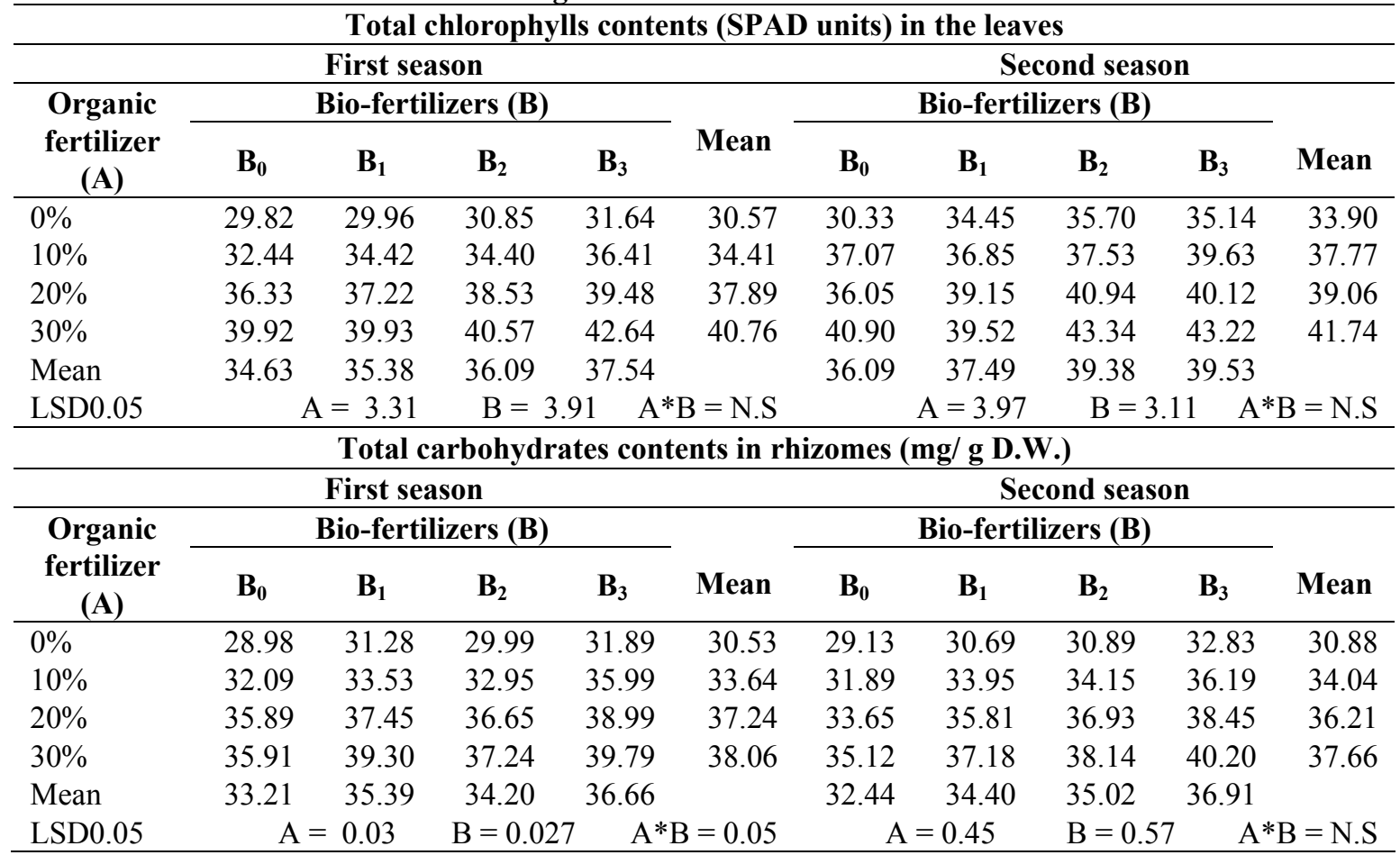

L.S.D. $0.05=$ least significant differences at 0.05 of probability.

N.S $=$ Non- significant differences at 0.05 of probability. 
For bio-fertilizers levels, any of bio-fertilizers application led to significant increases in the total leaf chlorophyll contents as comparing to control treatment $\left(\mathrm{B}_{0}\right)$. The increase in the total leaf chlorophyll contents was obtained by using application of (5 g Nitrobine $+5 \mathrm{~g}$ Phosphorein / pot) (37.54 and 39.53 SPAD, respectively), while the lowest total leaf chlorophyll contents was produced by untreated (control) (34.63 and 36.09 SPAD, respectively), in the both seasons.

The interactions between the using different organic fertilizers levels and bio-fertilizers levels, there were not significant differences in the leaf total chlorophyll content, in the both seasons.

The significant increase in total chlorophylls content may be due to the effect of mixture of biofertilizers and organic, which acted mainly in increasing the availability of nitrogen, consequently increasing its absorption by plant. It is well known that nitrogen is present in chlorophyll molecule. (Ridvan, 2009). Additionally, such increase in photosynthetic pigments formation could be attributed to the role of bio-fertilizers in producing certain phyto hormones consequent from microbiological activity Which delaying the aging of leaves by reducing the degradation of chlorophyll and enhancing the protein and RNA synthesis (Castelfranco and Beale, 1983).

These results were in agreement with Hussien (2004) on Iris plants, Sherif and El-Naggar (2005) on Calla lily plants, Atowa (2012) on Freesia refracta. ,Qasim, et al. (2014) on gladiolus cultivar, and Suseela, et al. (2016) on tuberose.

Total carbohydrates contents in rhizomes $(\mathrm{mg} / \mathrm{g}$ D.W.):

Data presented in Table (5), showed that there was significant effect of levels organic fertilizer on carbohydrate contents compared with control treatment. The highest contents was obtained by application organic fertilizer level 30\% (38.06 and $37.66 \mathrm{mg} / \mathrm{g}$ D.W, respectively), while the lowest contents was obtained by untreated (control) (30.53 and $30.88 \mathrm{mg} / \mathrm{g} \mathrm{D} . \mathrm{W}$, respectively) in the both seasons.

Moreover, bio-fertilizers treatments had a significant effect on carbohydrate contents of Cyperus alternifolius, L. plants compared with control treatment and the best result was recorded by $\mathrm{B}_{3}$ ( $5 \mathrm{~g}$ Nitrobine $+5 \mathrm{~g}$ Phosphorein / pot) ( 36.66 and $36.91 \mathrm{mg} / \mathrm{g} \mathrm{D} . \mathrm{W}$, respectively ), in the both seasons.

Concerning to the interaction between the using different organic fertilizers levels and bio-fertilizers levels, there were significant effect on carbohydrate contents of Cyperus alternifolius, L. plants in the first season, but there were not significant in the second season. The highest percentage was obtained by application organic fertilizer level $30 \%$ with $(5 \mathrm{~g}$ Nitrobine +5 g Phosphorein / pot) $(39.79 \mathrm{mg} / \mathrm{g}$
D.W), while the lowest percentage was obtained by $0 \%$ organic fertilizer (control) with untreated (control) of bio-fertilizers $(28.98 \mathrm{mg} / \mathrm{g} \mathrm{D} . \mathrm{W})$, in the first season.

These results might be attributed to both the activation of enzymes of carbohydrate formation or regulation of the consumption of sugars and contents of water and carbon dioxide absorption which could be led to increase the capacity of Cyperus alternifolius, L. plant in building metabolites, consequently the contents of total carbohydrates in the produced rhizomes could be increased. (Ridvan, 2009).

These results were in agreement with Hussien (2004) on Iris plants, EL-Naggar et al. (2004) on Cyperus papyrus, L., Atowa (2012) on Freesia refracta cv. Red Lion ,Kuo (2015) on Bermuda grass, and Suseela, et al. (2016) on tuberose cv. Suvasini.

\section{CONCLUSION}

The obtained results from this study revealed that addition of $30 \%$ / pot V/V from organic fertilizer with using bio-fertilizers level $(5 \mathrm{~g}$ Nitrobine $+5 \mathrm{~g}$ Phosphorein / pot) to growing media were produced a considerable increase in both vegetative growth and flowering as well as rhizomes productivity, total chlorophylls contents in leaves and total carbohydrates in rhizome on Umbrella Papyrus (Cyperus alternifolius, L.) plants.

\section{REFERENCES}

Abdou, M. A. H.; M. K. Aly, and A. S. A. Ahmed, (2013). Effect of compost, biofertilization and some vitamins Addition On Gladiolus grandiflorus. J. Plant Production, Mansoura Univ., Vol. 4 (12): 1751 - 1761.

Al-Fraihat, A.H.,; S. Y. A. Al-dalain,; Z. B. AlRawashdeh,; M. S. Abu-Darwish, and J.A. Al-Tabbal, (2011). Effect of organic and biofertilizers on growth, herb yield and volatile oil of marjoram plant grown in Ajloun region, Jordan. Journal of Medicinal Plants Research. 5(13): 2822-2833.

Atowa, D. I. (2012). Effect of growing media, organic and bio-fertilizers on growth and flowering of freesia refracta $\mathrm{cv}$. red lion. M. Sc. Thesis, Fac. Agri. Cairo Univ.

Bailey, L. H, (1962). The Standard Enycyclopedia of Horticulture Vol2. Mac Mill Lct. Co.

Barsoom, S.W. (1998). Comparative effects of inoculation with VA-mycorrhyzal fungi and organic matter addition on phosphorus and micronutrientsuptake by maize. Egypt. J. Soil Sci. 38:21-33.

Castelfranco, P.A., and S. I. Beale, (1983). Chlorophyll biosynthesis recent advances and areas of current interest. Ann. Rev. Plant. Physiol. 34:241-278. 
Chaliakhyan, M.Kh. (1957). Effect of Vitamins on growth and development of plants. Dokly Akad. Nauk. SSSK. 111:894-897.

Chaudhary, N. ; S.T. Kishan,; D. R. Biswas, and S. Geeta, (2013). Effect of integrated nutrient management on vegetative growth and flowering characters of gladiolus. Indian Journal of Horticulture; 70(1):156-159.

El- Deeb, M. B. E. M. (2016). Effect of mineral and bio- fertilization on the vegetative growth, flowering and corms production of Gladiolus plant growing under different media. Ph. D. Thesis, Fac. Agric., Alex Univ.

El-Fawakhry, F. M. ; A. H. El-Naggar and A. A. M. El-Naggar (2004) Physiological Studies on Growth And Flowering Of Cyperus Papyrus, L. - Effect Of Mineral Fertilization And Light Intensity. Alex. J. Agric Res.,49 (3):110-125.

El-Haddad, M. E.; Y. Z. Ishac, and M. I. Mostafa, (1993). The role of bio-fertilizers in reducing agricultural costs, decreasing environmental pollution and raising crop yield. J. Agric. Sci., Ain Shams Univ. (1):147- 159.

El-Naggar, A. H. (2010). Effect of bio-fertilizers , organic compost and mineral fertilizers on the growth, Flowering and bulbs production of Narcissus Tazetta, L. J.Agr ic.\&Env. Sci. Alex. Univ., Egypt. Vol. 9 (1).

El-Naggar, A. A. M.; A. H. EL-Naggar, and F. M. EL-Fawakhry, (2004). Physioligical studies on growth and flowering of Cyperus papyrus .1-Effects of growing media and water requirement. Alex. J. Agric Res.,49 (3): 93105.

Godse, S. B.; V. J. Golliwar,; C. Neha,; K. S. Bramhankar, and M. S. Kore, (2006). Effect of organic manures and bio-fertilizers with reduced doses of inorganic fertilizers on growth, yield and quality of gladiolus. Journal of Soils and Crops. 16(2): 445-449.

Gomez, K. A. and Gomez, A. A. (1984). Statistical procedures for Agricultural Research. 2nd Ed. John Wiley and sons, New York, USA.

Hasegawa, A.; M. Hashimoto,; S. Fukai, and A. Tajima, (1998 a). Dwarf Cyperus papyrus, L. for potted plants. Acta Hort., 454: 191-194.

Hasegawa, A.; T. Nagase,; M. Miki, and T. Takagi, (1998 b). Keeping quality of cut stem of Cyperus papyrus L. Technical Bull. Fac. Agric., Kagawa Univ., 50 (2): 115-123.

Herbert, D. ; P. J. Phlips, and R. F. Straange, (1971). Determination of total carbohydrates. Method., 58 : 209 - 344.

Hussien, H. S. M. (2004). Physiological studies on Iris plant. M. Sc. Thesis., Fac. Agric. Cairo Univ.
Iyamuremye, F. and R. P. Dick, (1997). Organic amendments and phosphorus sorption by soils. Adv. Agron. 56:139-185.

Jena, M.K.; P.K. Das, and A. K. Pattenaik, (1999). Integrated effect of microbial inoculants and fertilizer niterogen on $\mathrm{N}$-use efficiency and rhizome yield of turmeric (Curcuma longa L.). Orissa Journal of Horticulture, 27 (2): 10-16. (Hort. Abst., 71: 3559).

Jones, M. B. and S. W. Humphries, (2002). Impacts of the $\mathrm{C} 4$ sedge Cyperus papyrus. $\mathrm{L}$ on carbon and water fluxes in an African wetland Hydrobiology. November 2002, volume 488, Issue, 1-3.pp.

Kengne, I.M. mailto:ives kengne@yahoo.fr,; A. Amougou,; E.K. Soh,; V. Tsama; M.M. Ngoutane,; P.H. Dodane, and D. Koné, mailto:doulaye.kone@eawag.ch(2008).

Effects of faecal sludge application on growth characteristics and chemical composition of Echinochloa pyramidalis (Lam.) Hitch. and Chase and Cyperus papyrus L. Volume 34, Issue 3, 6 October, Pages 233-242.

Kiran, M.; J. Baloch,; K. Waseem,; M.S. Jilani, and K.M. Qasim, (2007). Effect of Different growing media on the growth and development of Dahlia (Dahlia pinnata) Under the Agro-Climatic Condition of Dera Ismail Khan. Pakistan Journal of biological Sciences 10 (22): 4140-4143.

Koreish, E. A.; M. E. El-Fayoumy,; H. M. Ramadan, and W. H. Mohamed (2004). Interaction effect of organic and mineral fertilization on faba bean and wheat productivity in calcareous soils. Alex,. J. Agric. Res.2: 101-114.

Koura, W. A. (2001). Effect of different growing media and fertilizer treatments on the growth of Canna indica L. plants. M. Sc. Thesis. Fac. Agri. Alex. Univ.

Kuo, Y. (2015). Effects of fertilizer type on chlorophyll contents and plant biomass in common Bermuda grass. Afr. J. Agric. Res. Vol. 10(42), pp. 3997-4000.

Qasim, M.; Adnan, Y.; Zahir, A. Z.; Atif, R. , Hassan, R. and T. Usman, (2014). Microbial Inoculation Increases The Nutrient Uptake Efficiency For Quality Production of gladiolus grandiflorus. Pak. J. Agri. Sci., Vol. 51(4), 875-880.

Ridvan, K. (2009). Nitrogen fixation capacity of Azotobacter spp. strains isolated from soils in different ecosystems and relationship between them and the microbiological properties of soils. J. Environ. Biol. 30(1), 73-82. 
Samira, S. A. and H. F. El-Tayeb, (2008). A comparative study for the effect of chemical and biofertilizers on growth, flowering, bulb productivity and chemical composition of Iris tingitana cv. Wedgwood plant. Alex. J. Agri. Res., 53 (2):63-70.

Satapathy S.P., R. Toppo,; M. Dishri, and C.R. Mohanty (2016) Impact of Integrated Nutrient Management (INM) on Flowering and Corm Production in Gladiolus. Biom Biostat Int J 4(7): 00119. DOI: 10.15406/bbij.2016.04.00119.

Shalaby, M.E., and M.F. El-Nady, (2008). Application of Saccharomyces cerevisiae as a biocontrol agent against Fusarium infection of sugar beet plants. Acta Biologica Szegediensis. 52(2):271-275.
Suseela, T.; R. Chandrasekha,; B. V. Vijaya,; D. R. S. Suneetha, and K. Umakrishna, (2016). Effect of organic manures, inorganic fertilizers and micronutrients on vegetative and floral characters of tuberose (Polianthes tuberosa L.) cv. 'Suvasini'. International Journal of Scientific and Research Publications, Volume 6, Issue 2. p 170-179.

Sherif, F. K. and A. El-Naggar, (2005). Effect of bio-fertilizers $\mathrm{s}$ application to manure on Calla lily (Zantedeschia aethiopical L. Spring) production and nutrients release in sandy soil. Alex. J. Agric. Res. 50 (1) 181-192.

Torkashvand, A. M.; H. Khanjani, and S. S. Hoor, (2015). Cow Manure Compost in Cultivation Bed and Irrigation Water Salinity on the Growth of Strelitzia Reginae. Trakia Journal of Sciences, No 2, pp 137-142,.

Yathindra, H.A.; M. R. Krishna,; A. M. Rajesh, and M. Harshavardhan, (2016). Effect of Integrated Nutrient Management on Growth Parameters of Bird of Paradise [Strelitzia Reginae (L.)]. International Quarterly Journal of Life Sciences. 11(1): 565-568. 


\section{المالهص العرم}

\section{تأثير النسميد المضوي والحيوي علل النمو والتركيب الكيميائي لنبلتل البري الفلالي}

\section{(Cyperus alternifolius, L.)}

\section{محمد رجب علي Rسن، علي مسن محمد النجار، أحمدمحمدفمل}

قبم الزهور ونباتلت الزينة وتنسق الحداقق - كلية الزراعة - جلمعة المسكندرية (للشطبى) - الاسكندرية - مصر

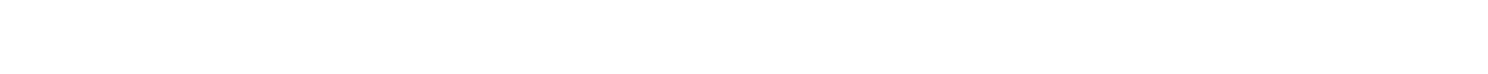

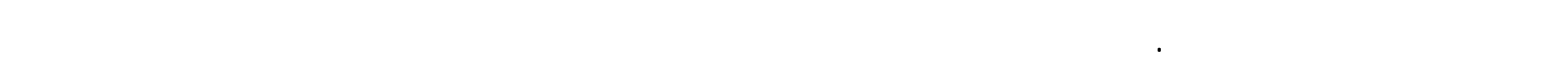

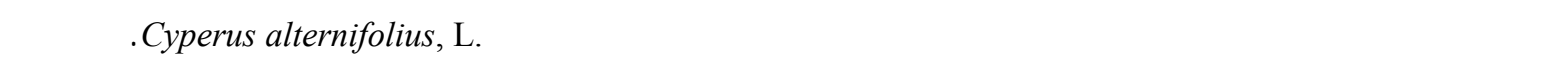

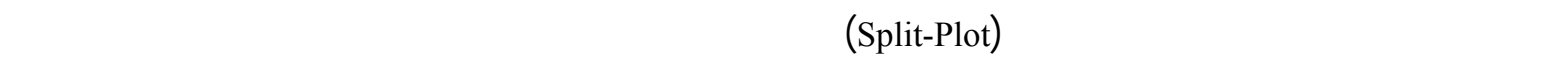

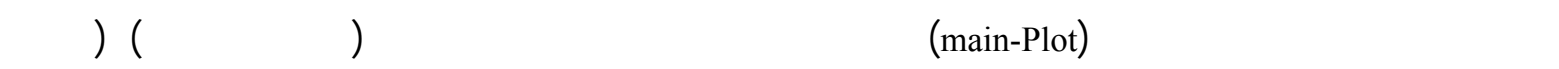

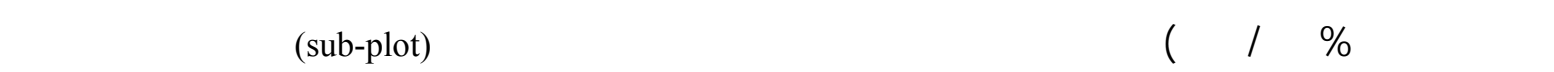

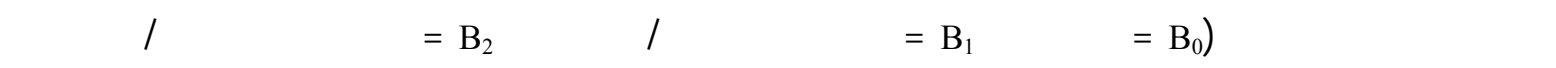
O 0 =B3

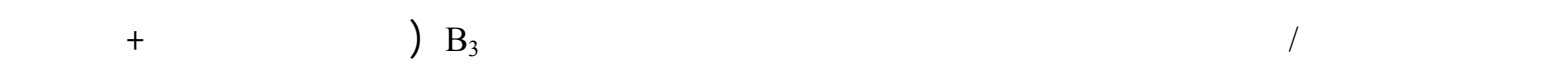

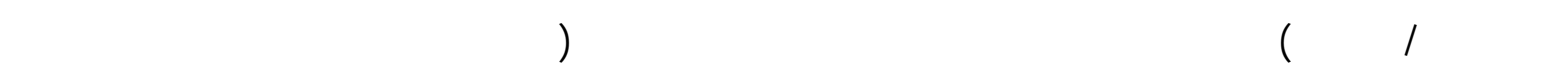

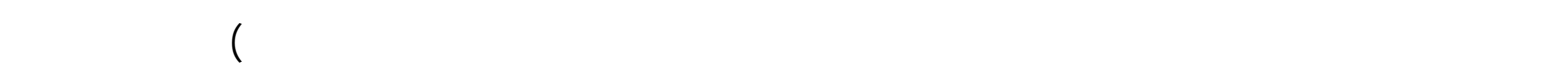

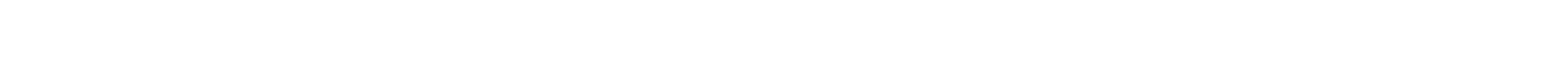

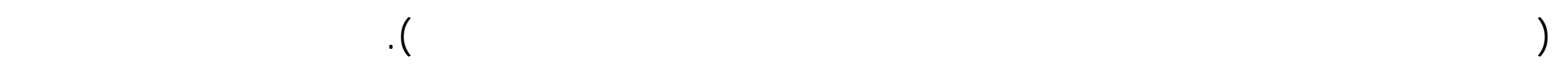

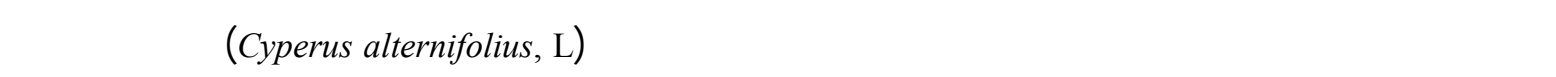

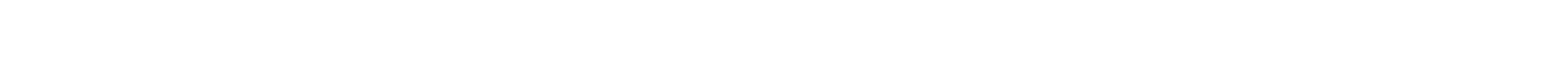
الحيوية بمعل 0 جرلم نيتروبين +0 جرلم فوسفورين / الصيص. 